Vol.3 No.1 Hal. $23-31$

Juni 2020

\title{
Hubungan Kualitas Kepemimpinan Kepala Sekolah dan Self Controlling Guru Dengan Kepuasan Kerja Guru SMA Swasta Medan Kota
}

\author{
Zul Aida \\ Dosen Pendidikan Biologi \\ Fakultas Keguruan Ilmu Pendidikan \\ Zul.aida@fkip.uisu.ac.id
}

\begin{abstract}
ABSTRAK
Penelitian ini bertujuan untuk mengetahui dan mendeskripsikan : 1)Hubungan Kualitas Kepemimpinan Kepala Sekolah dengan Kepuasan Kerja Guru SMA Swasta Medan 2)Hubungan Self Controlling guru SMA Swasta Medan dengan Kepuasan Kerja 3)Hubungan Kualitas kepemimpinan Kepala Sekolah, Self Controlling, Guru SMA Swasta Medan dengan kepuasan kerja. Metode yang digunakan dalam penelitian ini menggunakan metode penelitian deskriptif dengan jenis penelitian adalah penelitian korelasional untuk melihat hubungan antara variabel kualitas kepemimpinan kepala sekolah, Self Controlling, variabel guru dan variabel kepuasan kerja guru. Populasi dalam penelitian ini adalah guru SMA Swasta Kecamatan Medan Kota yang berjumlah 17 sekolah dengan jumlah guru 600 orang dengan jumlah sampel 234 orang guru. Sampel diambel berdasarkan Tabel Cohen Manion dan Morrison dengan tingkat kepercayaan 95\%. Instrument pengumpulan data adalah angket. Teknik analisis data yang digunakan adalah regresi korelasi. Berdasarkan perhitungan menggunakan analisis korelasi dan regresi, maka temuan yang diperoleh dengna kesimpulan bahwa : 1)terdapat hubungan positif dan signifikan antara variabel kualitas kepemimpinan kepala sekolah dengan kepuasan kerja dengan $\mathrm{r}$ $=0.350 ; 2$ )terdapat hubungan positif dan signifikan antara variabel Self Controlling dengan kepuasan kerja dengan $r=0,368$ dan 3)terdapat hubungan positif dan signifikan antara variabel kualitas kepemimpinan kepala sekolah dan Self Controlling secara bersama-sama terhadap kepuasan kerja dengan $\mathrm{r}=0,448$.
\end{abstract}

Kata Kunci : Hubungan ,Kualitas Kepemimpinan Kepala Sekolah, Kepuasan Kerja Guru, Self Controlling

\begin{abstract}
This study aims to determine and describe: 1) Relationship between Principal Leadership Quality and Job Satisfaction of Medan Private High School Teachers 2) Self-Controlling Relationship between Medan Private High School Teachers and Job Satisfaction 3) Relationship between Principal, Self Controlling, Leadership Leadership Quality, Medan Private High School Teachers with job satisfaction. The method used in this research uses descriptive research method with the type of research is correlational research to see the relationship between the quality of leadership principals, Self Controlling, teacher variables and teacher job satisfaction variables. The population in this study were high school private teachers in Medan Kota subdistrict, totaling 17 schools with 600 teachers with a sample of 234 teachers. Samples were taken based on the Cohen Manion and Morrison Tables with a 95\% confidence level. The data collection instrument was a questionnaire. The data analysis technique used is correlation regression. Based on calculations using correlation and regression analysis, the findings obtained with the conclusion that: 1) there is a positive and significant relationship between the quality of leadership principals with job satisfaction with $r=0.350 ; 2$ ) there is a positive and significant relationship between the variables of Self Controlling with job satisfaction with $r=0.368$ and 3) there is a positive and significant relationship between the variables of the quality of the principal's leadership and Self Controlling together with job satisfaction with $r=0.448$
\end{abstract}

Keywords : Relationships, Principal Leadership Quality, Teacher Job Satisfaction, Self Controlling 
Zul Aida : Hubungan Kualitas Kepemimpinan Kepala Sekolah dan Self Controlling Guru Dengan Kepuasan Kerja Guru SMA Swasta Medan Kota

\section{PENDAHULUAN}

\section{Latar Belakang}

Suatu bentuk kerja sama yang baik akan terlihat dari sikap yang diperlihatkan atau ditunjukkan seseorang, sesuai dengan pekejaan yang diberikan kepadanya, apakah sebagai pimpinan lembaga pendidikan, sebagai guru, sebagai pustakawan, sebagai laboran, atau sebagai petugas administrasi sekolah. Penunjukkan sikap yang baik dari para personil sekolah, menandakan adanya suatu perasaan puas dari dalam hatinya terhadap pekerjaan yang diberikan kepadanya. Kepuasan kerja yang diperlihatkan personil sekolah khususnya guru,dapat diamati dari kesungguhan hatinya menyelesaikan tugas - tugas yang menjadi tanggung jawabnya dengan waktu yang tepat, dengan dedikasi yang tinggi, memiliki semangat kerja yang tinggi, kerajinan kerja yang tinggi, ketekunan kerja yang tinggi, serta kreativitas kerja yang tinggi pula. Seorang pegawai merasa puas dengan apa yang diterimanya, akan menghasilkan kualitas dan produktivitas yang tinggi, dan sebaliknya apabila pegawai tidak merasakan kepuasan dalam tugas - tugasnya , maka dapat menimbulkan hal - hal yang merugikan dirinya bahkan juga bagi organisasi tempatya bekerja. Demikian juga halnya bila dikaitkan dengan pekerjaan seorang guru. Guru yang merasa puas atas apa yang diterimanya, dapat menghasilkan kualitas kerja, produktivitas kerja tinggi, namun sebaliknya bila tidak merasakan kepuasan dalam melaksanakan tugasnya, dapat menimbulkan kerugian, baik bagi dirinya, bagi peserta didik maupun bagi lembaga pendidikan. Wawancara yang penulis lakukan di Sekolah Menengah Atas Swasta Medan Kota, pada hari Jum'at tanggal 25 Mei 2012, menunjukkan adanya kinerja yang kurang baik, hal ini dilihat dari sikap diri (ketekunan,dedikasi) yang dapat diamati dari guru yang bertugas pada sekolah tersebut. Adapun moral kerja yang kurang baik adalah masalah kehadiran guru bertugas tepat waktu. Wawancara juga penulis lakukan terhadap siswa SMA Swasta Medan Kota. tentang guru mereka pada hari selasa, 5 Juni 2012 yang berkenaan dengan kepuasan kerja yang terlihat adanya moral kerja yang kurang baik, terdapat adanya sikap guru yang tidak mengindahkan peraturan sekolah. Adapun sikap guru yang tidak mengindahkan peraturan sekolah, masih adanya guru tidak hadir ke sekolah ketika jam mengajarnya dan masih terdapatnya guru yang juga ter- lambat datang ke sekolah untuk bertugas. Selain itu juga moral kerja juga tidak terbentuk pada dirinya, yang merupakan bentuk tanggungjawabnya sebagai seorang guru. Kualitas pimpinan merupakan kunci keberhasilan seseorang dalam memimpin. Kualitas pimpinan berhubungan erat dengan kemajuan dan perkem-bangan organisasi. Kualitas menjadi sangat penting bagi seorang pimpinan karena merupakan penentu kesuksesan dirinya dan organisasi yang dipimpinnya, demikian juga dengan orang-orang yang berada di bawah kepemimpinannya. Kualitas menjadi suatu keharusan yang harus dimiliki dalam membangun dan memimpin organisasi, tanpa kualitas, seorang pimpinan sulit membangun organisasi yang dipimpinnya. Kepemimpinan dirumuskan sebagai proses mempengaruhi kegiatan seseorang atau sekelompok orang dalam usaha pencapaian tujuan dalam situasi tertentu. Kalimat ini mengisyaratkan bahwa dalam kepemimpinan, ada orang yang menjadi pemimpin dikatakan sebagai pemimpin dan ada orang yang dipimpin dikatakan sebagai pengikut, serta berusaha semaksimal mungkin mempengaruhi perilaku mereka, dan bila pengaruh yang ditimbulkan berhasil maka para pengikut akan bekerja dengan maksimal. Dalam suatu lembaga pendidikan, kepala Sekolah merupakan pemimpin tertinggi dari personil lainnya, memiliki tanggung jawab penuh terhadap seluruh kegiatan sekolah, mempunyai inisiatif dan kreatif yang tinggi dalam mengarahkan perkembangan dan kemajuan sekolah. Mempunyai wewenang dan tanggung jawab untuk menyelenggarakan kegiatan - kegiatan atau pelatihan - pelatihan pada organisasi yang dipimpinnya. Kepala Sekolah tidak hanya bertanggung jawab atas kelancaran jalannya suatu organisaasi secara teknis akademis, tetapi mencakup 
Zul Aida : Hubungan Kualitas Kepemimpinan Kepala Sekolah dan Self Controlling Guru Dengan Kepuasan Kerja Guru SMA Swasta Medan Kota

segala kegiatan, keadaan lingkungan dengan kondisi dan situasinya serta hubungannya dengan masyarakat sekitarnya merupakan tanggungjawabnya juga. Inisiatif dan kreatifnya adalah ditujukan untuk kemajuan dan perkembangan organisasi yang dipimpinnya, walaupun menemui berbagai kesulitan dan hambatan dalam pelaksanaannya di sekolah. Dalam menghadapi semua hambatan dan kesulitan, dibutuhkan seorang kepala Sekolah yang berkualitas. Untuk dapat menjadi seorang kepala Sekolah yang berkualitas, tentu haruslah memiliki sejumlah kemampuan, keahlian, pengetahuan, ide - ide, fungsi - fungsi, dan kinerja yang tinggi. Kinerja seorang kepala Sekolah yang berkualitas dapat dilihat dari beberapa indikator yaitu sebagai educator, manager, administrator, supervisor, leader, inovator dan motivator

\section{Perumusan Masalah}

Berdasarkan penjelasan yang telah diungkapkan pada latar belakang masalah, identifikasi masalah dan pembatasan masalah, maka masalah penelitian ini dapat dirumuskan sebagai berikut:

1. Apakah terdapat hubungan kualitas kepemimpinan kepala Sekolah dengan kepuasan kerja guru SMA Swasta Medan Kota?

2. Apakah terdapat hubungan self controling guru SMA Swasta Medan Kota dengan kepuasan kerja?

3. Apakah terdapat hubungan kualitas kepemimpinan kepala Sekolah dan self controlling guru SMA Swasta Medan Kota dengan kepuasan kerja?

\section{Tujuan Penelitian}

Sesuai dengan rumusan masalah di atas, maka penelitian ini bertujuan :

1. Hubungan kualitas kepemimpinan kepala Sekolah dengan kepuasan kerja guru SMA Swasta Medan Kota.

2. Hubungan self controlling guru SMA Swasta Medan Kota dengan kepuasan kerja.

3. Hubungan kualitas kepemimpinan kepala Sekolah, self controlling guru SMA Swasta Medan Kota dengan kepuasan kerja.

\section{Manfaat Penelitian}

Secara teoritis penelitian ini diharapkan dapat memberikan manfaat dan sumbangan pemikiran serta bahan acuan bagi kepala Sekolah dan para guru, khususnya para guru SMA Swasta Medan Kota, di samping itu hasil penelitian ini dapat memperkaya khasanah ilmu pengetahuan khususnya dalam bidang Administrasi Pendidikan, tentang kualitas kepemimpinan kepala Sekolah dan self controlling guru SMA Swasta Medan Kota dengan kepuasan kerja. Dengan mengetahui persentase hubungan antara variabel dalam penelitian ini, diharapkan hasil penelitian ini menjadi bahan masukan bagi : (a) Kepala Sekolah untuk memiliki kualitas kepemimpinan yang baik (b) Para guru, untuk memiliki self controlling yang baik guna mengembangkan potensi-potensi peserta didik serta membentuk kepribadiannya. 
Zul Aida : Hubungan Kualitas Kepemimpinan Kepala Sekolah dan Self Controlling Guru Dengan Kepuasan Kerja Guru SMA Swasta Medan Kota

\section{METODE PENELITIAN}

\section{Tempat dan Waktu Penelitian}

Penelitian ini dilaksanakan di SMA Swasta Kecamatan Medan Kota. Penelitian ini dilakukan mulai Bulan Maret 2013 sampai Juni 2013.

\section{Metode Penelitian}

Penelitian ini menggunakan pendekatan kuantitatip studi korelasional. Pendekatan studi korelasional dipilih, karena penelitian ini menguji hubungan antara variabel.Pendekatan korelasional diarahkan untuk melihat ada tidaknya hubungan antara variabel tanpa adanya perlakuan.

\section{Populasi dan Sampel}

Populasi dalam penelitian ini adalah seluruh guru SMA Swasta Kecamatan Medan Kota yang berjumlah 17 sekolah. Masing-masing sekolah memilih akreditasi yang berbeda yakni akreditasi A dengan jumlah guru 459 orang, akreditasi B dengan jumlah guru 116 orang dan dan akreditasi $C$ yang berjumlah 25 orang sehingga populasi berjumlah 600 orang. Penentuan pengambilan sampel yang dilakukan penelitian adalah berdasarkan Tabel Cohen Manion dan Morrison (1989) dengan tingkat kepercayaan 95\% sehingga sampel berjumlah 234 orang guru dengan rincian 179 orang guru yang berasal dari sekolah berakreditasi A, 45 orang guru berasal dari sekolah dengan akreditasi B dan 10 orang guru berasal dari sekolah berakreditasi $\mathrm{C}$.

\section{Teknik Pengumpulan data}

Instrument penelitiaan digunakan untuk mengungkapkan data penelitian guna menguji hipotesis penelitian. Instrument yang digunakan dalam penelitian ini berbentuk angket. Angket digunakan untuk mengungkap data penelitian kualitas kepemimpinan $\left(\mathrm{X}_{1}\right)$, dan self controlling $\left(\mathrm{X}_{2}\right)$, kepuasan kerja guru $(\mathrm{Y})$.

\section{Teknik Analisis Data}

Adapun tahapan - tahapan yang dilakukan dalam analisis data penelitian adalah sebagai berikut :

1. Menyajikan data dalam bentuk tabel distribusi frekuensi dan histrogram. Selanjutnya dari masing - masing data penelitian ditentukan dengan nilai - nilai maksimum, minimum, rata - rata, standart deviasi, varians, modus dan median.

2. Melakukan pengujian persyaratan analisis data sebelum melakukan pengujian hipotesis penelitian. Adapun persyaratan analisis adalah (a) Pengujian normalitas data dengan uji normalitas galat taksiran variabel terikat terhadap variabel bebas, dengan uji yang digunakan adalah uji Lileofors. Kriteria pengujian yang dilakukan adalah menerima galat taksiran variabel yang terikat berdistribusi normal terhadap variabel bebas, jika Lo > Ltabel pada taraf signifikan $\mathrm{a}=0,05$ dengan $\mathrm{dk}=\mathrm{n}$ (b) Pengujian Homoginitas varians dengan uji Barlet. Adapun kriteria pengujiannya adalah menerima varians $\mathrm{Y}$ atas $\mathrm{X}$, homogen jika X2 $\mathrm{h}>\mathrm{X} 2$ tabel, taraf signifikan $\mathrm{a}=0,05$ dengan $\mathrm{dk}=\mathrm{k}-1$ (c) Pengujian pada linieritas regresi dan keberartian koefisien regresi linier, dilakukan dengan Anava. Adapun kriteria pengujiannya adalah, terima model regresi $\mathrm{Y}$ atas $\mathrm{X}$, jika $\mathrm{F}$ hitung $>\mathrm{F}$ tabel, dan terima koefisiensi regresi linier berarti, jika $\mathrm{F}$ hitung $<\mathrm{F}$ tabel.

3. Melakukan pengujian hipotesis penelitian.

Setelah semua persyaratan pengujian pada analisis data telah terpenuhi, maka langkah selanjutnya adalah melakukan pengujian hipotesis. 
Zul Aida : Hubungan Kualitas Kepemimpinan Kepala Sekolah dan Self Controlling Guru Dengan Kepuasan Kerja Guru SMA Swasta Medan Kota

\section{HASIL DAN PEMBAHASAN}

1. Variabel Kaulitas Kepemimpinan Kepala Sekolah $\left(\mathbf{X}_{1}\right)$

Hasil pengolahan data menunjukkan untuk variabel kualitas kepemimpinan kepala sekolah memiliki skor minimum 140; skor maksimum 191; skor rata-rata 168,42; modus 174; median 170; standar deviasi 9,7 dan varians 94,11. Perhitungan dapat dilihat pada Lampiran 3. Gambaran tentang distribusi frekuensi data variabel kualitas kepemimpinan kepala sekolah disajikan dalam Tabel 1.

Tabel 1. Distribusi Data Skor Variabel Kualitas

Kepemimpinan Kepala Sekolah

\begin{tabular}{|c|ccc|c|c|}
\hline No & \multicolumn{3}{|c|}{ Kelas Interval } & $\mathrm{f}_{\mathrm{i}}$ & $\mathrm{f}_{\mathrm{i} \text { relatif }}$ \\
\hline 1 & 140 & - & 145 & 7 & 3,0 \\
2 & 146 & - & 151 & 11 & 4,7 \\
3 & 152 & - & 157 & 18 & 7,7 \\
4 & 158 & - & 163 & 27 & 11,5 \\
5 & 164 & - & 169 & 41 & 17,5 \\
6 & 170 & - & 175 & 85 & 36,3 \\
7 & 176 & - & 181 & 30 & 12,8 \\
8 & 182 & - & 187 & 14 & 6,0 \\
9 & 188 & - & 193 & 1 & 0,4 \\
\hline Jumlah & \multicolumn{7}{|r|}{} & & 234 & 100 \\
\hline
\end{tabular}

Berdasarkan Tabel 1. dapat dijelaskan bahwa skor rata-rata berada pada kelas interval 164 169 , yang artinya sebanyak $17,5 \%$ skor responden berada pada skor rata-rata, 26,92\% berada di bawah skor rata-rata dan 55,56\% berada di atas skor rata-rata. Selanjutnya histogram skor variabel kualitas kepemimpinan kepala sekolah disajikan pada gambar 1berikut :

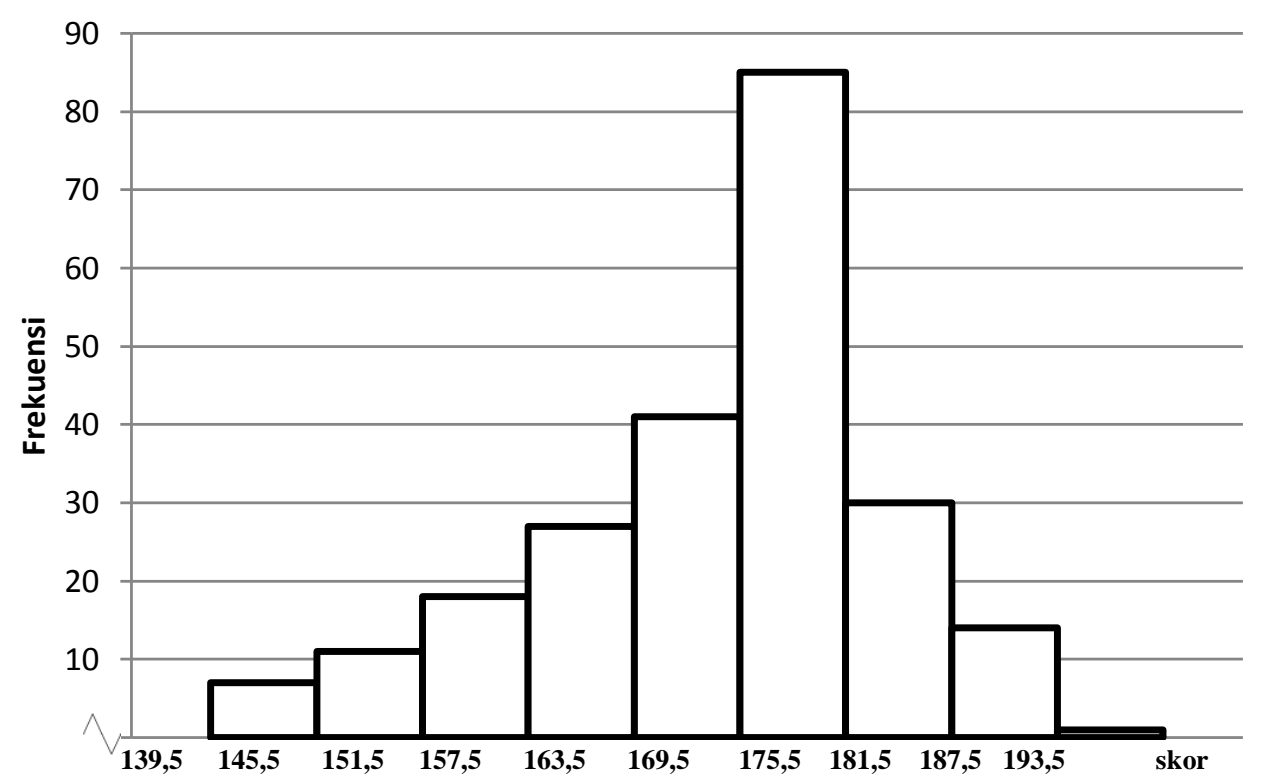

Gambar 1. Histogram Skor Variabel Kaulitas Kepemimpinan Kepala Sekolah

\section{Variabel Self controlling $\left(\mathrm{X}_{2}\right)$}

Hasil pengolahan data menunjukkan untuk variabel self controlling memiliki skor minimum 74; skor maksimum 114; skor rata-rata 96,53; modus 90; median 95, standar deviasi 7,82 dan varians 61,18 . 
Zul Aida : Hubungan Kualitas Kepemimpinan Kepala Sekolah dan Self Controlling Guru Dengan Kepuasan Kerja Guru SMA Swasta Medan Kota

Gambaran tentang distribusi frekuensi data variabel self controlling disajikan dalam Tabel 2.

Tabel 2. Distribusi Data Skor Variabel Self controlling

\begin{tabular}{|c|ccc|c|c|}
\hline No & \multicolumn{3}{|c|}{ Kelas Interval } & $\mathrm{f}_{\mathrm{i}}$ & $\mathrm{f}_{\mathrm{i} \text { relatif }}$ \\
\hline 1 & 74 & - & 78 & 2 & 0,85 \\
2 & 79 & - & 83 & 2 & 0,85 \\
3 & 84 & - & 88 & 23 & 9,83 \\
4 & 89 & - & 93 & 74 & 31,62 \\
5 & 94 & - & 98 & 37 & 15,81 \\
6 & 99 & - & 103 & 43 & 18,38 \\
7 & 104 & - & 108 & 33 & 14,10 \\
8 & 109 & - & 113 & 19 & 8,12 \\
9 & 114 & - & 118 & 1 & 0,43 \\
\hline Jumlah & \multicolumn{7}{|c}{} & & 234 & 100 \\
\hline
\end{tabular}

Berdasarkan Tabel 2. dapat dijelaskan bahwa skor rata-rata berada pada kelas interval 94 - 98, yang artinya sebanyak $15,81 \%$ skor responden berada pada skor rata-rata, $43,16 \%$ berada di atas skor rata-rata dan $41,03 \%$ berada di atas skor rata-rata. Selanjutnya histogram skor variabel self controlling disajikan pada gambar 2 berikut :

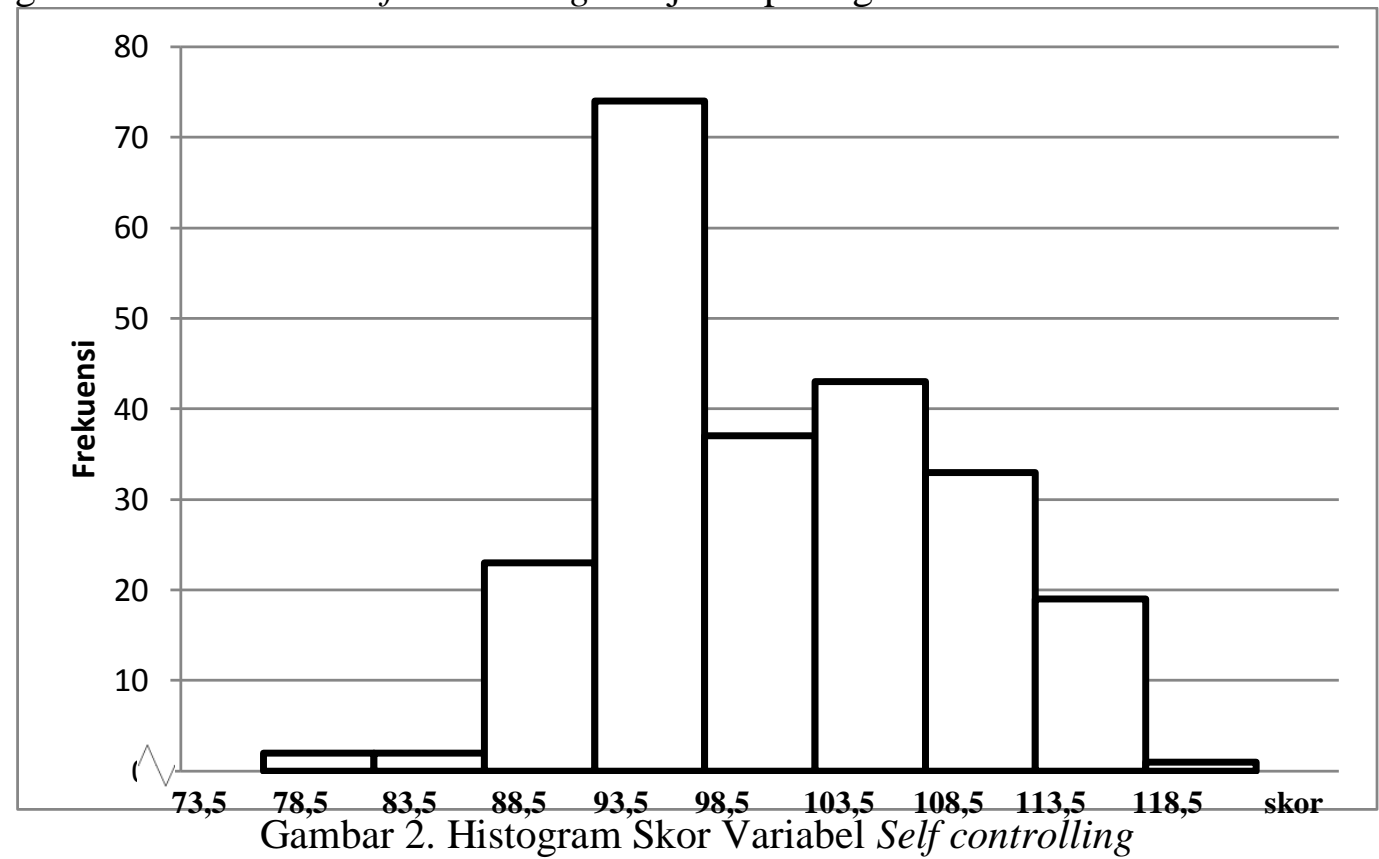

\section{Terdapat Hubungan Positif dan Signifikan antara Kualitas Kepemimpinan dan Kepuasan Kerja}

Berdasarkan hasil perhitungan statistik diperoleh kesimpulan bahwa terhadap hubungan positif dan signifikan antara kualitas kepemimpinan dan kepuasan kerja dengan sumbangan efektif sebesar $12,65 \%$. Berdasarkan simpulan ini diketahui bahwa semakin baik kualitas kepemimpinan yang dimiliki kepala sekolah maka akan semakin baik pula tingkat kepuasan kerja guru di sekolah. Kualitas kepemimpinan berkaitan dengan karakter dari dari seorang pemimpin sebagai strategi untuk meraih keunggulan ataupun pertumbuhan suatu organisasi. 
Pemimpin yang berkualitas adalah pemimpin yang mampu menghadapi dan mengikuti perkembangan ilmu pengetahuan dan teknologi. Pemimpin yang berkualitas mampu menghadapi berbagai permasalahan dan mengambilan keputusan untuk membuat kebijakan. Kepemimpinan yang berkualitas sangat diperlukan untuk pertumbuhan dan kemajuan suatu organisasi. Kepemimpinan yang berkualitas dicirikan dengan pemimpin yang memiliki karakter yang baik, berkarisma, berkomitmen, mampu berkomunikasi dengan baik, berkompetensi, memiliki keberanian, fokus, murah hati, memiliki inisiatif tinggi, suka mendengarkan bawahan, mempunyai semangat yang tinggi, memiliki sikap positif, mampu dan berusaha memecahan masalah dengan baik, memiliki dan menjaga hubungan, mempunyai rasa tanggungjawab mempunyai rasa kemapanan, disiplin diri, memberikan pelayanan, memiliki sikap mau diajar dan memiliki visi yang jelas. Karakter pemimpin yang berkualitas mampu memberikan pengaruh terhadap lingkungan di sekelilingnya. Karakter positif yang ditunjukkan juga akan dinilai positif oleh lingkungan dan secara tidak langsung juga akan berpengaruh positif terhadap lingkungan, termasuk kepuasan kerja bawahan atau pegawainya. Kepuasan kerja berkaitan dengan perasaan yang dirasakan seseorang terhadap pekerjaannya berupa kepuasan terhadap gaji, kepuasan terhadap promosi, kepuasan terhadap rekan kerja, kepuasan terhadap penyelia dan kepuasan terhadap pekerjaan itu sendiri. Kepuasan kerja guru dapat ditunjukkan dari sikapnya dalam bekerja, dan bila guru merasa puas terhadap pekerjaannya, maka guru akan melaksanakan pekerjaannya dengan baik, yang terlihat dari sikap diri yang ditunjukkannya dari dirinya dan pelayanan yang diberikannya untuk melayani peserta didiknya, sebaliknya bila merasa tidak puas terhadap pekerjaannya, maka ia akan bekerja dengan sesuka hatinya, tanpa mengindahkan ketentuan yang berlaku. Kualitas kepemimpinan yang baik akan mempengaruhi kepuasan kerja guru. Kepala sekolah yang memiliki kepemimpinan yang berkualitas mampu memberikan pengaruh positif terhadap guru-guru.Kepala sekolah yang baik mampu memotivasi dan mendorong sikap positif, mampu menumbuhkan rasa percaya serta hubungan yang baik dengan guru. Guru yang memiliki persepsi positif terhadap kepemimpinan kepala sekolah memiliki rasa percaya terhadap atasannya, akan memiliki tanggungjawab terhadap pekerjaannya. Guru bekerja dengan sungguh-sungguh atas dasar tanggungjawab dan kewajiban bukan karena takut dengan kepala sekolah. Sikap positif seorang guru terhadap pekerjaan mencerminkan kepuasan terhadap pekerjaan yang diembannya. Sehingga secara tidak langsung persepsi positif guru terhadap kepala sekolah akan mempengaruhi kepuasan kerja guru. Dari uraian di atas dapat dikatakan bahwa kualitas kepemimpinan dapat meningkatkan kepuasan kerja guru dalam melaksanakan pekerjaannya, maka dapat disimpulkan bahwa terdapat hubungan positif antara kualitas kepemimpinan terhadap kepuasan kerja guru.

\section{Hubungan Self Cotrolling Guru dengan Kepuasan Kerja}

Self controlling adalah kemampuan untuk mengontrol tingkah laku sendiri, kemampuan untuk menekan dan mengatasi tingkah laku impulsif.Self controlling penting bagi setiap diri manusia, demikian juga guru, harus mempunyai self controlling yang baik, tidak membiasakan diri dikendalikan oleh naluri, tetapi harus mengendalikannya dengan rasio, akal sehat dan kebersihan hati nurani. Setiap guru mempunyai self controlling yang berbeda - beda dalam menyelesaikan permasalahan hidupnya, baik yang berhubungan dengan masalah pribadinya maupun pekerjaaannya. Self controlling yang baik perlu dipertahankan oleh setiap guru, karena pekerjaan guru berhubungan dengan banyak orang yakni dengan kepala sekolah, para wakil kepala sekolah, para guru, petugas administrasi, laboran, pustakawan, peserta didik, dan para orang tua dari peserta didik.Untuk peserta didik, seorang guru diharuskan memberikan pelayanan belajar terbaik yang berlangsung di dalam kelas.Guru bertanggung jawab memberikan layanan belajar kepada peserta didiknya, baik layanan belajar dalam bentuk teori maupun praktik. Untuk dapat memberikan layanan yang 
baik pada seluruh peserta didiknya, maka seorang guru haruslah memiliki pengetahuan, kepribadian dan self controlling yang baik pula. Dengan dimilikinya self controlling yang baik, maka seorang guru dapat menjalankan tugas dan tanggung jawabnya dengan baik dan, hal ini dapat diperoleh bila guru dapat berfikir jernih dan tenang, maka perilaku akan terpelihara dan penjagaan diri akan tetap dapat terjaga, demikian pula sebaliknya jika guru tidak memiliki self controlling yang baik, maka dapat memberikan dampak buruk karena dapat mengalami ketegangan fikiran dan berperilaku aneh. Guru yang tidak memiliki self controlling yang baik, akan tercermin dalam sikapnya terhadap lingkungan di sekitar, termasuk di depan siswa. Perilaku negatif guru akan menjadi contoh yang buruk terhadap siswa dan secara tidak langsung akan berpengaruh pada iklim pembelajaran di kelas dan akhirnya berpengaruh pada hasil belajar yang diperoleh siswa. Guru yang memiliki self controlling yang baik menggunakan perasaannya secara proporsional sehingga dapat memperlakukan peserta didik secara objektif, tetapi dengan penuh perasaan kasih sayang, bukan perasaan subjektif. Guru yang memiliki self controlling yang baik akan berpengaruh positif terhadap perkembangan jiwa peserta didiknya, dan dapat menjadi teladan bagi siswa. Dengan demikian guru yang mengembangkan potensi akal budinya dalam menjalankan tugasnya, akan memberikan yang terbaik bagi peserta didiknya. Seorang guru yang mempunyai self controlling yang baik, haruslah memiliki kesadaran diri dan pengelolaan diri yang baik, dengan adanya kompetensi pribadi ini, akan mampu menyesuaikan diri terhadap berbagai permasalahan yang dihadapinya. Self controlling tercermin dari tingkah laku guru yang tenang dan bijaksana dalam mengambil keputusan.Bersikap mengayomi terhadap siswa dan membina hubungan baik dengan setiap siswa dan pandai menempatkan diri baik sebagai guru, teman atau orang tua. Guru dengan self controlling yang baik merasa bahwa mengajar adalah kewajiban dan harus dilakukan dengan sepenuh hati. Guru mengajar dengan senang hati dan berusaha menciptakan suasana belajar yang menyenangkan di kelas.Kegiatan mengajar menjadi sesuatu yang menyenangkan dan bukan menjadi beban dan pada akhirnya guru merasakan kepuasan terhadap setiap pekerjaan yang dilakoninya. Dari uraian di atas dapat dikatakan perlunya self controlling yang baik bagi seorang guru, maka dapat disimpulkan bahwa terdapat hubungan self controlling guru dengan kepuasan kerja

\section{KESIMPULAN}

Berdasarkan hasil penelitian tindakan kelas yang telah dilaksanakan, maka dapat disimpulkan bahwa :

1. Terdapat hubungan positif dan signifikan antara kualitas kepemimpinan dengan kepuasan kerja guru. Artinya semakin tinggi dan positif kualitas kepemimpinan kepala sekolah maka semakin tinggi dan positif pula kepuasan kerja guru dengan memberikan sumbangan yang efektif sebesar $12,65 \%$. Hal ini diartikan bahwa variasi yang terjadi pada variabel kualitas kepemimpinan kepala sekolah sebesar 12,65\% dapat diprediksi dalam meningkatkan kepuasan kerja guru.

2. Terdapat hubungan positif dan signifikan antara self controlling dengan kepuasan kerja guru. Artinya semakin tinggi dan positif self controlling maka semakin tinggi dan positif pula kepuasan kerja guru dengan memberikan sumbangan yang efektif sebesar 7,89\% hal ini dapat diartikan bahwa variasi yang terjadi pada variabel self controlling sebesar $7,89 \%$.dapat diperediksi dalam meningkatkan kepuasan kerja guru.

3. Terdapat hubungan positif dan signifikan secara bersaman-sama antara kualitas kepemimpinan kepala sekolah dan self controlling dengan kepuasan kerja guru. Artinya semakin tinggi dan positif kualitas kepemimpinan kepala sekolah dan self controlling kerja maka semakin tinggi dan positif pula kepuasan kerja guru. 
Zul Aida : Hubungan Kualitas Kepemimpinan Kepala Sekolah dan Self Controlling Guru Dengan Kepuasan Kerja Guru SMA Swasta Medan Kota

\section{DAFTAR PUSTAKA}

Atkinson, Hilgard, 1983, Pengantar Psikologi, Erlangga, Jakarta.

Arikunto, S., 2002, Dasar-Dasar Evaluasi Pendidikan, Bumi Aksara, Jakarta

Azwar, S., 2004, Sikap Manusia, Teori dan Pengukurannya, Pustaka Pelajar, Yogyakarta

Berhanuddin, 1994, Analisis Administrasi Manajemen dan Kepemimpinan Pendidikan, Bumi Aksara, Jakarta.

Colquit, Lepine, Wessen, 2009, Organizationan Behaviour, US, ME Grons, Hills.

Danim, Sudarwan, 2002, Inovasi Pendidikan, Pustaka Setia, Bandung

Daryanto, 1994, Administrasi Pendidikan, Rineka Cipta Solo.

Gimson, A.C. 1963, Oxford Advanced Learner's Dictionary Of Current English, University College, London

Handoko,T.Sani, 2000,Manajemen Personalia Dan Sumber Daya Manusia,BPFE, Yogyakarta

Hasibuan, Malayu, 2003, Manajemen Sumber Daya Manusia, Bumi Aksara, Jakarta

Istiana, S, 2005, Psikologi Sosial, Kalangan Sendiri, Medan

Mar'at, 1981, Sikap Manusia, Perubahan serta Pengukuran, Ghalia Indonesia, Jakarta

Metia, Cut, 2009, Psykologi Kepribadian, Cipta Pustaka, Medan.

Mulyasa, E. 2004, Menjadi Kepala Sekolah Profesional dalam Konteks Mensukseskan MBS dan KBK, PT. Rosdakarya, Bandung.

Muslim dan Sri Banun, 2008, Supervisi Pendidikan Meningkatkan Kualitas Profesionalisme Guru, Beta, Bandung.

Pidarta, Made, 2007, Landasan Kependidikan, Rineka Cipta, Jakarta

Purba, Suparman, 2010, Kinerja Pimpinan Jurusan di Perguruan Tinggi, Laks, Bang PRESSindo, Yogyakarta.

Purwanto, Ngaling, 1987, Administrasi dan Supervisi Pendidikan, PT. Rosdakarya, Bandung.

Rivai, Mulyadi, 2011, Kepemimpinan Dan Perilaku Organisasi, Rajawali Press, Jakarta

Robbins, Stephen, P., 1996, Essensial Of Organizatonal Behavior, New Jersy, Prentice Hall

Sagala, Syaiful., 2010, Supervisi Pembelajaran, Alfabeta, Bandung.

Sagala, Syaiful, 2009, Administrasi Pendidikan Kontenporer, Alfabeta, Bandung.

Siagian, Sondang, P, 2002, Fungsi-Fungsi Manajerial, Bumi Aksara, Jakarta.

Silalahi, Ulber, 2009, Metode Penelitian Sosial, Refika Aditama, Bandung.

Sinar Grafika, 2003, Undang-Undang Sikdiknas, Sinar Grafika, Jakarta.

Sutisna, Oteng, 1963, Administrasi Pendidikan, Penerbit Angkasa Bandung.

Sudjana, 1983, Teknik Analisis Regresi dan Korelasi, Bandung : Tarsito.

Supandi, 1996. Administrasi dan Supervisi Pendidkan.Jakarta ; Departemen Agama Universitas Terbuka.

Suprihatin, MD. 1989. Adminsitrasi Pendidkan, Fungsi dan Tanggunjawab Kepala Sekolah sebagai Administrator dan Supervisor Sekolah.Semarang : IKIP Semarang Press.

Thoha, Miftah, 1983, Kepemimpinan Dalam Manajemen, Rajawali, Press, Jakarta.

Yukl, Gery, 2001, Kepemimpinan Dalam Organisasi, Bumi Aksara, Jakarta 